\title{
ELECTROSURGICAL MICRONEEDLE VERSUS SCALPEL SKIN INCISIONS IN THE FACIAL REGION
}

\author{
Peneva Margarita, ${ }^{1}$ Gjorgjeska Andrijana, ${ }^{1}$ Dzokik Gjorgje, ${ }^{1}$ GinoskiVladimir, ${ }^{1}$ \\ Breshkovska Hristina, ${ }^{1}$ Dzoleva Tolevska Roza ${ }^{2}$ \\ ${ }^{1}$ University Clinic for Plastic and Reconstructive Surgery, Medical Faculty, \\ Ss. Cyril and Methodius University, Skopje, Republic of Macedonia \\ ${ }^{2}$ University Clinic for Orthopedic surgery, Medical Faculty, \\ Ss. Cyril and Methodius University, Skopje, Republic of Macedonia
}

Primljen/Received 16. 09. 2018. god.

Abstract: Objective: Electrosurgery is widely used in surgical procedures, but mainly for subcutaneous and deep layer dissections. The aim of this study was to clinically evaluate the results of routine use of electrosurgical microneedle in performing skin incisions in the facial regions. Material and methods: Eighty patients with both benign and malignant skin lesions in the facial regions undergoing surgery were enrolled in this study. In group A comprising 40 patients, cold steel surgical scalpel $\mathrm{N}^{\circ} 15$ was used for the surgical procedure. Electrosurgical microneedle with $0.06 \mathrm{~mm}$ tip radius and generator unit KLS Martin Electrosurgical Unit ME MB 2 set on cutting mode, power $12 \mathrm{~W}$ was used for performing the surgery in group B including the same number of patients. Differences between incision time, excision time, blood loss and the wound related complications were evaluated. Results: The two groups did not significantly differ in the speed of incision and speed of excision although both the speed of incision and the speed of excision were found to be slightly faster in the electrosurgery group. There was significantly less blood loss in the electrosurgery group compared with the scalpel group.Statistical analysis did not confirm as significant the difference in complications between the two groups although most of the complications were associated with the patients operated with scalpel. Conclusion: Electrosurgery presents safe and effective way of work. In that manner, it is very important to choose the right generator unit's settings and the right type of electrode.

Key words: surgical scalpel, electrosurgery, facial regions.

\section{INTRODUCTION}

Surgical scalpel is the most widely used cutting instrument in surgery. The incisions made with the
Prihvaćen/Accepted 12. 11. 2018. god.

scalpel are sharp and very precise causing only mechanical injury to the tissue together with profound bleeding. Different types of scalpel are used for different procedures in surgery $(1,2)$.

However, over the years different alternative ways for cutting the skin have been developed with electrosurgery being the most popular one (3). Electrosurgery involves the passage of high frequency alternating electrical current in the tissues to produce the effect of cutting or coagulation $(3,4)$.

In recent years there has been a huge improvement in the design of electrosurgical devices thus making electrosurgery safe and effective method for work. But although it is widely used in surgical procedures, mainly for subcutaneous and deep layer dissections its use on skin has been precluded by the fear of complications like delayed wound healing and surgical site infections (4). In that manner it is very important to choose the right generator unit's settings and the right type of electrode.

In order to achieve the effect of the scalpel, pure cut mode with the generator unit output power set on the lowest power that can produce the effect of cutting combined with an electrode in form of needle or microneedle should be used for cutting the skin $(5,6)$. The microneedle electrode with the tip radius of $0.06 \mathrm{~mm}$ is used for performing fine surgical procedures $(1,7,8)$.

The aim of this study was to clinically evaluate the results of routine use of electrosurgical microneedle in performing skin incisions in the facial regions.

\section{MATERIALS AND METHODS}

Eighty patients with both benign and malignant skin lesions in the facial regions undergoing surgery were enrolled in this study. The patients were recruited 
from the University Clinic for Plastic and Reconstructive Surgery, Medical Faculty, Ss. Cyril and Methodius University in Skopje, Macedonia, in the time interval between September 2017 to September 2018.

Patients were randomized in two groups using the envelope randomization method. Each group included 40 patients. In group A cold steel surgical scalpel $N^{\circ} 15$ was used for the surgical procedure whereas electrosurgical microneedle with $0.06 \mathrm{~mm}$ tip radius and generator unit KLS Martin Electrosurgical Unit ME MB 2 set on cutting mode, power $12 \mathrm{~W}$ was used for performing the surgery in group B. Electrosurgery was used for hemostasis during the dissection process in both groups using the same generator unit set on coagulation mode power $20 \mathrm{~W}$.

Surgical procedures were performed under local infiltrative anesthesia (lidocaine $1 \%$ with adrenalin) as to standard practice.

In each surgical procedure the proposed skin excision was marked. When the excision was a circle its perimeter was calculated using the standard formula and when the excision was an ellipse its perimeter was calculated using the Ramanujan formula. The time required to complete the incision was calculated. The incision included cutting of the epidermis and dermis. Incision was considered completed when hypodermis was reached. The perimeter in millimeters divided by the time in seconds gave the speed of incision movement $(\mathrm{mm} / \mathrm{s})$.

Only the tip of the microneedle was allowed to come in contact with the proposed incision line while the sides of the microneedle were not allowed to touch the skin edges at any time. To avert the skin edges away as cutting precedes, the surgeon and assistant applied mild traction pressure on either side of the skin incision.

The time needed to complete the excision was calculated. In all the cases only skin and superficial part of the subdermal tissue were excised. The excision was considered completed with the completion of the haemostasis.

Blood loss was also calculated. First dry gauze swabs were measured and then the gauze swabs soaked with blood. The difference between the two measurements was considered the total blood loss. One gram of blood was regarded as equivalent of $1 \mathrm{ml}$ of blood. No suction evacuation of blood was done while making the skin incision.

On completing total skin excision, the vitality of the skin was evaluated by checking its color and blood supply. Wound edges were inspected for any thermal trauma in form of fulguration and dermal peeling.

At the termination of the operation the postoperative defect was closed in manner of direct closure where there was no tension or with the use of local skin flaps in order to release the tension. Wound closure was achieved in two layers with interrupted sutures.
The subcutis was sutured with $3 / 0$ Polyglactin 910 while the skin was sutured with silk fibroin $4 / 0$.

Wound complications occurring at any stage after the operation and at one month follow up were recorded. Each wound was inspected for wound healing complications comprising wound infection, dehiscence, necrosis, and haematoma.

All the patients were informed about the nature of the skin incision and written informed consent was signed.

\section{RESULTS}

Statistical analysis of the data was performed using the statistical program Statistics for Windows 7,0. A value of $p<0,05$ was considered statistically significant.

Both groups of patients were homogenous according to the sex structure $(p=0.64)$. The mean age of the patients in group A was $61.45 \pm 19.8$ and the mean age of the patients in group B was $69.03 \pm 11.9$.

The indication for surgery in terms of underlying diagnosis did not differ significantly between the groups and malignancy was diagnosed in majority of patients in each group.

The velocity of incision was analyzed in $\mathrm{mm} / \mathrm{s}$ from the start of cutting till completing the incision. The speed of incision when steel scalpel was used ranged $2.6 \pm 1.1 \mathrm{~mm} / \mathrm{s}$ while the speed of incision when microneedle electrosurgery was used ranged $2.95 \pm 1.2$ $\mathrm{mm} / \mathrm{s}$. The speed of incision although not significantly was found to be slightly faster in the group B $(2.6 \pm$ 1.1 vs $2.95 \pm 1.2 ; \mathrm{p}=0.17$ ) (Table 1 ).

The speed of excision was also analyzed. Excision included excision of skin and superficial part of the subcutaneous tissue. Excision was considered completed with the completion of the hemostasis. The speed of the excision was registered as non-significantly faster in group B in our study $(1.74 \pm 1.1$ vs. $1.97 \pm 1.0 ; p$ $=0.33)($ Table 2$)$.

Table 1. Speed of Incision

\begin{tabular}{|l|c|c|c|c|}
\hline \multirow{2}{*}{ Groups } & \multicolumn{3}{|c|}{ Speed of incision $(\mathrm{mm} / \mathrm{s})$} & \multirow{2}{*}{$\mathrm{p}$ value } \\
\cline { 2 - 4 } & $\mathbf{n}$ & $\mathbf{m e a n} \pm \mathbf{S D}$ & $\min -\mathbf{m a x}$ & \\
\hline Scalpel & 40 & $2.6 \pm 1.1$ & $0.7-5.1$ & \multirow{2}{*}{$0.17 \mathrm{~ns}$} \\
\hline Microneedle & 40 & $2.95 \pm 1.2$ & $0.7-6.3$ & \\
\hline
\end{tabular}

$\mathrm{p}$ (Student t-test)

Table 2. Speed of Excision

\begin{tabular}{|l|c|c|c|c|}
\hline \multirow{2}{*}{ Groups } & \multicolumn{3}{|c|}{ Speed of excision $\left(\mathrm{mm}^{2} / \mathrm{s}\right)$} & \multirow{2}{*}{ v value } \\
\cline { 2 - 4 } & $\mathbf{n}$ & mean \pm SD & $\min -\mathbf{m a x}$ & \\
\hline Scalpel & 40 & $1.74 \pm 1.1$ & $0.4-6.7$ & \multirow{2}{*}{$0.33 \mathrm{~ns}$} \\
\hline Microneedle & 40 & $1.97 \pm 1.0$ & $0.5-5.1$ & \\
\hline
\end{tabular}

$\mathrm{p}$ (Student t-test) 
Table 3. Blood Loss

\begin{tabular}{|l|c|c|c|c|}
\hline \multirow{2}{*}{ Groups } & \multicolumn{3}{|c|}{ Blood loss $\left(\mathrm{ml} / \mathrm{mm}^{2}\right)$} & \multirow{2}{*}{ p value } \\
\cline { 2 - 4 } & $\mathbf{n}$ & mean \pm SD & min - max & \\
\hline Scalpel & 40 & $0.017 \pm 0.013$ & $0.003-0.062$ & \multirow{2}{*}{0.00089 sig } \\
\hline Microneedle & 40 & $0.009 \pm 0.006$ & $0.002-0.03$ & \\
\hline
\end{tabular}

$\mathrm{p}$ (Student t-test)

Table 4. Complications in general

\begin{tabular}{|l|c|c|c|c|}
\hline \multirow{2}{*}{$\begin{array}{c}\text { Complications } \\
\text { in general }\end{array}$} & \multicolumn{3}{|c|}{ Treatment } & \multirow{2}{*}{ p value } \\
\cline { 2 - 4 } & $\mathbf{n}$ & Scalpel & Microneedle & \\
\hline No & 62 & $30(75 \%)$ & $32(80 \%)$ & \multirow{2}{*}{$0.59 \mathrm{~ns}$} \\
\hline Yes & 18 & $10(25 \%)$ & $8(20 \%)$ & \\
\hline
\end{tabular}

$\mathrm{p}$ (Chi-square test)

Table 5. Complications

\begin{tabular}{|c|c|c|c|c|}
\hline \multirow{2}{*}{ Complications } & \multicolumn{3}{|c|}{ Treatment } & \multirow{2}{*}{$\mathrm{p}$ value } \\
\hline & $\mathrm{n}$ & Scalpel & Microneedle & \\
\hline \multicolumn{5}{|l|}{ Infection } \\
\hline No & 77 & $40(100)$ & $37(92.5)$ & \multirow{2}{*}{${ }^{\mathrm{b}} 0.24 \mathrm{~ns}$} \\
\hline Yes & 3 & 0 & $3(7.5)$ & \\
\hline \multicolumn{5}{|l|}{ Hematoma } \\
\hline No & 75 & $36(90)$ & $39(97.5)$ & \multirow{2}{*}{${ }^{\mathrm{b}} 0.36 \mathrm{~ns}$} \\
\hline Yes & 5 & $4(10)$ & $1(2.5)$ & \\
\hline \multicolumn{5}{|c|}{ Delayed wound healing } \\
\hline No & 67 & $31(77.5)$ & $36(90)$ & \multirow{2}{*}{${ }^{\mathrm{a}} 0.13 \mathrm{~ns}$} \\
\hline Yes & 13 & $9(22.5)$ & $4(10)$ & \\
\hline \multicolumn{5}{|c|}{ Dehiscence - partial } \\
\hline No & 69 & $32(80)$ & $37(92.5)$ & \multirow{2}{*}{${ }^{\mathrm{a}} 0.1 \mathrm{~ns}$} \\
\hline Yes & 11 & $8(20)$ & $3(7.5)$ & \\
\hline \multicolumn{5}{|l|}{ Necrosis } \\
\hline No & 71 & $33(82.5)$ & $38(95)$ & \multirow{2}{*}{${ }^{\mathrm{b}} 0.15 \mathrm{~ns}$} \\
\hline Yes & 9 & $7(17.5)$ & $2(5)$ & \\
\hline
\end{tabular}

${ }^{a} \mathrm{p}$ (Chi-square test) ${ }^{\mathrm{b}} \mathrm{p}$ (Fisher exact, two tailed)

When the blood loss was measured as $\mathrm{ml} / \mathrm{mm}^{2}$ there was significant difference between the two groups for the value $\mathrm{p}=0.00089$. The mean blood loss was significantly lower in the group of patients operated with electrosurgery $(0.009 \pm 0.006$ vs $0.017 \pm 0.013)$ (Table 3).

Results of this study showed that complications had $25 \%$ of the patients in the scalpel group and $20 \%$ of the patients in the microneedle group. Statistical analysis did not confirm as significant the difference in complications between the two groups $(\mathrm{p}=0.59)$ (Table 4).

The patients in both groups did not significantly differ in the postoperative complications $(p>0.05)$, al- though of the complications were associated with the patients operated with scalpel (Table 5).

Macroscopic signs for thermal trauma as charcoal effect together with dermal peeling was noticed in two patients and only dermal peeling in only one patient. Prolonged wound healing and partial wound dehiscence was noticed in only one patient, one of the patients with signs of fulguration and dermal peeling.

In our study the postoperative complications were not significantly associated with smoking $(\mathrm{p}=0.54)$.

\section{DISCUSSION}

Wound healing of the skin after surgical incision is a primary factor affecting patient morbidity and recovery time. Although electrosurgical instruments are used increasingly for making deep layer incisions and tissue dissection, concerns about excessive scaring, high wound infection rate and poor wound healing have restricted the widespread use of electrosurgery for skin incisions.

Improvements in the design of electrosurgical devices have created generators that produce pure sinusoidal cut waveforms that cause minimal thermal damage to the tissue. This coupled with specialized cutting tips like microneedle can make a skin incision that does not differ from scalpel incision.

Several previous studies have investigated the use of electrosurgery in skin opening. Most were connected with general surgery and mainly for abdominal and thoracic skin incisions. They have shown that there is no difference in the wound healing between the wounds created with steel scalpel and the wounds created with electrosurgery (10-19).

The study of Sheikh B. et al. recommend the use of microneedle electrosurgery surgery in all neurosurgical procedures especially when blood loss has significant importance, such as in paediatric cases (20).

Similar results were shown in the study of Kumar and al. which analyses the outcome of patients following use of scalpel and electrosurgery in elective skin incisions of head and neck cancer. Due to the reduced blood loss and shorter operative time they strongly recommend the use of electrosurgery in these group of patients.

In our study the two groups did not differ significantly in the both incisional and excisional speed although both the incisional and excisional time were faster in the electrosurgery group. There was significantly less blood loss in the electrosurgery group compared with the scalpel group. There is no change in wound complications rate in the electrosurgery group. More over in our study most of the complications were associated with the patients operated with scalpel. 
On the base of this study it is suggested that the skin may be safely incised with electrosurgery. Furthermore, the recent increase in blood borne disease makes exclusion of the scalpel from the operative field an attractive option and the role of scalpel in making incisions may be completely taken over by the electrosurgery.

\section{CONCLUSION}

Electrosurgery is safe and effective way of performing elective surgical procedures in the facial region.
The findings of this study support the use of microneedle in surgical procedures concerning the facial region.

\section{DECLARATION OF INTEREST}

The authors declare that there are no conflicts of interests.

This study was done as a part of a more extended $\mathrm{PhD}$ thesis.

\section{Licensing}

This work is licensed under a Creative Commons Attribution 4.0 International (CC BY 4.0) License.

\title{
Sažetak
}

\section{POREĐENJE ELEKTROHIRURŠKIH KOŽNIH INCIZIJAMIKROIGLOM I KOŽNIH INCIZIJA SKALPELOM U PREDELU LICA}

\author{
Peneva Margarita, ${ }^{1}$ Gjorgjeska Andrijana, ${ }^{1}$ Dzokik Gjorgje, ${ }^{1}$ GinoskiVladimir, \\ Breshkovska Hristina, ${ }^{1}$ Dzoleva Tolevska Roza ${ }^{2}$ \\ ${ }^{1}$ University Clinic for Plastic and Reconstructive Surgery, Medical Faculty, \\ Ss. Cyril and Methodius University, Skopje, Republic of Macedonia \\ ${ }^{2}$ University Clinic for Orthopedic surgery, Medical Faculty, \\ Ss. Cyril and Methodius University, Skopje, Republic of Macedonia
}

Uvod: Elektrohirurgija se šrroko koristi u hirurškim procedurama, ali uglavnom za potkožne i duboke disekcije. Cilj ove studije bio je da se klinički proceni rezultat rutinskog korišćenja elektrohirurške mikrogle za kožne incizije u predelu lica. Materijal i imetode: $U$ studiju je uključeno osamdeset pacijenata sa benignim $i$ malignim lezijama kože u predelu lica koji su operisani. U grupi A, koja se sastojala od 40 pacijenata, korišćen je hirurški skalpel broj 15. Grupa B je imala isti broj pacijenata i tu je korišćen elektrohirurška mikroigla sa radijusom $0.06 \mathrm{~mm}$ i generatorskom jedinicom KLS Martin Electrosurgical Unit ME MB2 postavljen na režim sečenja, snage $12 \mathrm{~W}$. Vrednovane su razlike između vremena incizije, vremena ekscizije, gubitka krvi i komplika-

\section{REFERENCES}

1. Petrovski M, Kaftandziev I, Petrovski D, Zhogovska E, Cvetanovski V, Todorovik L et al. Surgical propaedeutics, practicum for exercises. 1st ed. Skopje: Makavej, 2006.

2. Scalpel in Wikipedia. Retrieved June 16, 2017, from https://en.wikipedia.org/wiki/Scalpel.

3. Panovski M. Electrosurgery. 1st ed. Skopje: Tabernacle, 2013.

4. Sharma R. Safety of Colorado microdissection needle (Stryker) for skin opening in craniomaxillofacial surgery. J Maxillofac Oral Surg. 2012; 11(1): 115-8.

5. Honig WM. The mechanism of cutting in electrosurgery. IEEE Trans Biomed Eng. 1975; 22(1): 58-62. cija vezanih za ranu. Rezultati: Dve grupe se nisu značajno razlikovale u brzini incizije i ekscizije, iako su se ove dve vrednosti pokazale nešto brže u grupi gde je korišćena elektrohirurška mikroigla. Bilo je značajno manje gubitka krvi u grupi B u poređenju sa grupom gde je korišćen skalpel. Statistička analiza nije potvrdila značajnu razliku u komplikacijama između dve grupe, iako je većina komplikacija bila povezana sa pacijentima kod kojih je korišćen skalpel. Zaključak: Elektrohirurgija predstavlja bezbedan i efikasan način rada. Važno je odabrati odgovarajuće postavke generatorske jedinice $\mathrm{i}$ odgovarajući tip elektrode.

Ključne reči: hirurški skalpel, elektrohirurgija, region lica.

6. KLS MARTIN group. Electro surgery manual. Available at: http://www.klsmartin.com/fileadmin/Inhalte/Downloads_Prospekte/HF-Geraete/90-604-02-04_09_06_Handbuch_HF.pdf. Accessed June 15, 2017.

7. Dixon AR, Watkin DF. Electrosurgical skin incision versus conventional scalpel: a prospective trial. J R Coll Surg Edinb. 1990; 35(5): 299-301.

8. Vore SJ, Wooden WA, Bradfield JF, Aycock ED, Vore PL, Lalikos JF, et al. Comparative healing of surgical incisions created by a standard "bovie", the Utah Medical Epitome Electrode, and a Bard-Parker cold scalpel blade in a porcine model: a pilot study. Ann Plast Surg. 2002; 49(6): 635-45.

9. Berríos-Torres SI, Umscheid CA, Bratzler DW, Leas B, Stone EC, Kelz RR, et al.. Centers for Disease Control and Pre- 
vention Guideline for the Prevention of Surgical Site Infection, 2017. JAMA Surg. 2017; 152(8): 784-91.

10. Ravikumar V, Siddiqui YMB, Vajpeyi V, Vickey Katheria V. Comparative analysis between scalpel and diathermy in elective abdominal incisions. IJMHS. 2'15; 5:2; 50-2.

11. Aird LN, Brown CJ. Systematic review and meta-analysis of electrosurgery versus scalpel for surgical skin incisions. Am J Surg. 2012; 204(2): 216-21.

12. Shekhar U. Naval B.Electrosurgery versus scalpel incision in inguinal hernioplasty. RJPBCS. 2013; 4 (4): 499-503.

13. Groot G, Chappell EW. Electrosurgery used to create incisions does not increase wound infection rates. Am J Surg. 1994; 167(6): 601-3.

14. Kearns SR, Connolly EM, McNally S, McNamara DA, Deasy J. Randomized clinical trial of diathermy versus scalpel incision in elective midline laparotomy. Br J Surg. 2001; 88(1): 41-4.

15. Allan SN, Spitz L, van Noort R, Black MM. A comparative study of scalpel and electrosurgical incision on subsequent wound healing. J Pediatr Surg. 1982;17(1): 52-4.

16. Eisenmann D, Malone WF, Kusek J. Electron microscopic evaluation of electrosurgery. Oral Surg Oral Med Oral Pathol. 1970; 29(5): 660-5.
17. Chrysos E, Athanasakis E, Antonakakis S, Xynos E, Zoras O. A prospective study comparing diathermy and scalpel incisions in tension-free inguinal hernioplasty. Am Surg. 2005; 71(4): 326-9.

18. Byrne FJ, Kearns SR, Mulhall KJ, McCabe JP, Kaar K, Gilmore M, et al. Diathermy versus scalpel incisions for hemiarthroplasty for hip fracture: a randomized prospective trial. Eur J OrthopSurgTraumatol. 2007 Jul 25. [Epub ahead of print] PubMed.

19. Shah Kalawar RP, Khanal GP, Chaudhary P, Rijal R, Maharjan R, Paneru SR, et al. Comparative study of safety and efficacy of electrosurgery blade with cold scalpel blade for skin Ooening during fixation of fracture of forearm bone with plate and screws. International Journal of Chemical and Biomedical Science. 2015; 1(2): 52-5.

20. Sheikh B. Safety and efficacy of electrosurgery scalpel utilization for skin opening in neurosurgery. Br J Neurosurg. 2004; 18(3): 268-72.

21. Kumar V, Tewari M, Shukla HS. A comparative study of scalpel and surgical diathermy incision in elective operations of head and neck cancer. Indian J Cancer. 2011; 48(2): 216-9.

\section{Correspondence to/Autor za korespondenciju}

Margarita Peneva MD MSc.

University Clinic for Plastic and Reconstructive surgery

Medical Faculty, Ss. Cyril and Methodius University, Skopje, Republic of Macedonia

Address: Blvd. Partizanski odredi 117-3/8,

1000 Skopje, Republic of Macedonia

Mob. phone: +38970255303

E-mail: mapeneva@yahoo.com; margarita.peneva@plasticsurgery.com.mk 